\title{
THE USE OF THE GRAVITY MODEL IN FORECASTING THE FLOWS OF EMIGRANTS IN EU COUNTRIES
}

\author{
Nicolaie IANCU ${ }^{\mathrm{a}}$, Alina BADULESCU ${ }^{\mathrm{b}}$, Ramona-Mihaela URZICEANU ${ }^{\mathrm{a}}$, \\ Elena-Ana IANCU ${ }^{\mathrm{a}}$, Ramona SIMUT ${ }^{\mathrm{b}}$ \\ ${ }^{a}$ Agora University, Department of Social Sciences, No. 8 Tineretului Street, Oradea, 410526 Romania \\ ${ }^{b}$ University of Oradea, Department of Economics, No.1 Universitatii Street, Oradea, 410087 Romania
}

Received 13 February 2015; accepted 23 January 2016

\begin{abstract}
Migration is a complex phenomenon with economic, social, political, cultural and human implications, and therefore, it is the locus of interest for many researchers from various fields. After 1989, migration in Romania became a social issue due to the large number of migrants searching for labour all around Europe. This paper focuses on investigating and forecasting labour migration from Romania and its geographical orientation. We analysed the gravity model, which simple and accurate, focused on the distance as a determinant of the length of the mobility and, thus, of the host country chosen by the migrant. Based on the proposed macroeconomic model, we discuss results for main destinations countries, i.e. Spain, Italy, Austria, Germany, as well as for EU as a whole.
\end{abstract}

Keywords: labour migration, Romania, forecast, outgoing migration, EU destination countries.

JEL classification: J61.

\section{Introduction}

The international migration of workers and the policies on migration applied by the authorities are major, consistent, often multidisciplinary concerns, crowning the efforts of many researchers and practitioners from various fields: economists, sociologists, demographers and political scientists, to discuss and explain the determinants and consequences of migration. Even in its legal, organized varieties (not to mention the dramatic illegal border crossings by land or sea), migration is a costly act in economic, cultural and human terms.

\section{Labour migration - the main component of migration in Romania after 1989}

Most studies agree that migration was one of the "most ubiquitous socio-economic phenomena in Romania since the fall of communism in 1989" (IOM 2008). The extent of the

Corresponding author Nicolaie Iancu

E-mail:niancu2009@yahoo.com 
phenomenon is highlighted by the fact that, in about 20 years, between 10 and $15 \%$ of the Romanian population have fled the country, and an even higher number is involved at present in various forms of circular migration, tempered only by the global phenomenon of the economic crisis.

To provide you with a brief overview, the migration phenomenon began abruptly immediately after the Revolution of December 1989, when, by the opening of borders, an estimated 97,000 people emigrated in one year, followed by another 170,000 people over the next three years. Basically, it's a continuation of ethnic migration: during this period, the ethnic migrations bound for Germany, Hungary and Israel underwent their final phase (Diminescu 2009: 45-62; Badulescu 2007a, 2007b; Badulescu et al. 2015) but there was also an increase of the Romanian ethnic component in the migratory flows.

In the years that followed, the visa restrictions and the economic difficulties and political instability did not reduce migration, but gave it a temporary and circular character, the main motivation being, at least seemingly, an economic one.

The EU accession in 2007 and the subsequent international economic crisis have not changed much of this profile; they might only have caused some structural changes in the composition of flows, destinations, education level of the migrants, etc.

Labour migration, including both temporary and circular migration, is the most noticeable component of Romanian migration in recent decades and in the whole post-communist period (IOM 2005; Andrén, Roman 2014). Here, as with other economic and demographic phenomena, the official data reflecting it, when there are any, are quite inconsistent, and often indicate values different from those provided by surveys or obtained from comparative sources - such as those on the outflows - in the Romanian records, respectively on the entries - in the records of the destination countries. Some figures are relevant: in 2005, 13\% of the households had an average of 1.5 members working abroad, i.e. about 1.4 million labour migrants (CURS 2005). Moreover, a survey conducted by the Open Society Foundation - Romania, on the Romanian labour migration in 1990-2006, pointed out that more than $33 \%$ of the Romanian households had had at least one migrant at work abroad during 1990-2006 period (Sandu 2006: 8). The reports of the Department for Work Abroad (within the Ministry of Labour, Family and Equal Opportunities), of 2005 and 2006, include data on the number of employment contracts concluded through government or private agencies. According to these reports, in 2005, 42,758 employment contracts were mediated by the state institutions and, in 2006, another about 61,200, most of these contracts belonging to the agriculture and construction fields, to which a further 15,000 contracts mediated by private agencies in 2006 were added.

If the data recorded present numerous variations regarding the number of Romanians having left to work abroad, with regard to the nature of their occupations abroad the data of surveys and of the official institutions are more convergent. Thus, in 2005, the professional position of Romanian labour emigrants shows a dominance of labour employed in agriculture (food production) and constructions sector, followed by employment in households, hotel services, restaurants and similar activities and so on (CURS 2005). 


\section{The gravity model - a brief overview}

In the specialized literature, there are numerous approaches and models for the study of labour migration/mobility. Many of them give an explanation either of international versus internal migration or of inter-regional migration in Europe versus the rest of the world, and its role as adjustment mechanism within the European Union (Arpaia et al. 2014).

Among the methods of approaching labour migration, there are: the Markov chains, the Harris-Todaro models, models of the economic influence of labour mobility within Europe, models for the researchers' mobility, models for the flexible wages' influence on the labour mobility etc.

In this paper, we present the gravity model and several results of its application, more specific the results of applying a panel model for the study of Romanian migration.

The gravity model is the simplest and most suggestive macroeconomic model of migration, being centered on the relationship between distance and the inclination to travel. The most important scientist who laid the foundations of this theory is geographer Ernst Georg Ravenstein, who, in his work "Laws of Migration" of 1885 (Ravenstein 1885), promoted the idea that migration is governed by processes of the "push-pull" type, exerting either a pushing out pressure (of the push type), such as: adverse economic conditions, oppressive laws, high taxes, or a pulling in pressure (of the pull type), such as favourable conditions in foreign locations. Ravenstein's laws emphasize that the foremost motivation for migration is economic, stating that:

1. Most people migrate only for short distances and thus generate "migration streams" to large urban centres;

2. This causes dislocation processes and population growth in the sending, respectively receiving areas;

3. The processes of absorption and dispersion are interconnected;

4. The migration chain and channels develop over time;

5. The migration channels lead the population movement especially towards commercial and industrial centres;

6. Urban residents are less prone to migration than rural population;

7. Women are less probable to migrate than men.

Briefly, the gravity model of migration shows that the number of migration events between two regions is directly proportional to the number of inhabitants in each area and inversely proportional to the square of the distance between the sending area and the receiving area. Its mathematical expression is reflected in the following equation:

$$
M_{i j}=K \frac{P_{i} P_{j}}{D_{i j}},
$$

where: $M_{(i j)}=$ the number of migrants leaving from location i to location $j ; K=$ a constant; $P_{i}=$ the population of location $i ; P_{j}=$ the population of location $j ; D_{(i j)}=$ the distance between the two locations.

The above formula and the laws stated find numerous empirical confirmations in the history of human migration; the gravity model thus appears as an empirical generaliza- 
tion of the large migration flows in history. However, the model cannot explain why there are considerable variations in the characteristics of migrants, or the differences in volume between migratory flows that start from similar countries. For example, on basis of this model, one could have predicted that the next big wave of migration should occur between Russia, China and India, as they fulfil the conditions laid down: they are large states with large populations (especially the last two) and relatively close geographically. However, data shows that there is no significant movement between them. Another example that contradicts the universality of the model is the preference of the 19th and 20th centuries' migrants for countries with large areas, with a low population density, such as the U.S., Australia, Canada and so on, or the consistent migration flow between Pakistan and the UK in the past 50 years. In this example, the considerable distance should have significantly reduced the result according to the model, the discrepancy with the theory confirming our assumption that the migration in question had other explanations than those provided by this model.

One way to increase the explanatory force of the model would be to enrich it with the elements discussed above, such as taking into account the transport costs, the obstacles met during the movement or cultural, historical and other kinds of factors, while accepting, however, its theoretical dilution.

\section{Literature on using the gravity model for investigating labour migration}

Many methods used in estimating international migration are based on deterministic mathematical models or different quantitative techniques, but, contrasting with the deterministic methods, the stochastic (probabilistic) instruments for the analysis and forecasting of migration are rooted in the probability theory. Stochastic models are used more frequently than the deterministic ones because they present greater possibilities for tackling the uncertainty of migration and forecasting.

Since migration theories are too fragmented, the only option in order to obtain plausible analyses and predictions on the population flows is to use methods and models both deterministic and probabilistic, which are potentially related.

Migration is considered the neoclassical economists as the result of big disparities in economic opportunities over the world, especially in revenues. In addressing the human capital of migration, Sjaastad (1962) gives up the assumption of homogeneous labour. Depending on their skill levels, individuals calculate the value of their human capital for each region or country. Each individual assesses his/her return and costs in a different way, so that migration to a country may be useful to some people and not useful to others. Therefore, in the analysis of the structure of the migration flows one should not only pay attention to the aggregate labour market variables (such as wages and the unemployment gap), but to individuals' heterogeneity as well.

Almost all empirical studies use aggregate databases in order to find a statistically significant positive effect of income or wages in the destination country, or the wage differences between the destination countries and origin countries, as well as a negative effect of the income and wages in the migrants' decision to return to their country of origin (Martin, Radu 
2012; Lang et al. 2012). Several studies further investigate factors determining individuals to make the decision to migrate, such as the lack of jobs, the migrants' qualification etc.

There is no commonly-agreed precise definition of the extremely qualified and no standardized treatment of this notion in the statistics of different countries and organizations. There are, however, two evaluations, which play an important role in virtually all definitions related to high qualifications: the first refers to qualifications obtained through studies graduation (according to this parameter, those who are graduates of higher education are regarded as very highly qualified or highly qualified), the second relates to the profession in question, the quality of high qualification being identified by the type of work that the person conducts in the country of destination.

Education and training (as well as health care) are considered as key investment in the human capital formation. These will result, at a later stage, in a better labour employment that will lead to the achievement of higher revenues by the persons concerned.

They are also considered crucial to the performance levels of national economies: a higher level of education of the workforce will lead to higher economic growth and employment.

Because economic growth in today's societies and economies is a much higher level than in the past and is driven by innovation, investment in knowledge is seen today as more important than ever.

In the case of highly skilled migrants, the destination country receives human capital as a gift. It has achieved a "brain" gain, while the origin country has suffered a "brain exodus". It should be noted that usually we speak of a "brain gain" and "brain drain" only if the number of migrants is considerable, and if the balance between highly skilled immigrants and emigrants is highly disproportionate. Situations characterized by a relative balance are instead often referred to as "brain exchange". As a result, today it is possible to quantify, more or less correctly, the stock of migrants in a given country, and the flows within a particular period. As long as these flows cannot be measured correctly, the brain gain will remain a matter of hypothesis. Therefore, some researchers argue that as long as the emigration of the highly skilled is not permanent, it would be more appropriate to speak in neutral terms of the "brain circulation", "brain mobility" or "circulation of the elites".

Also, the migration of the highly skilled does not necessarily lead to a brain gain for the country of destination. This is possible if, for example, a migrant who is a nuclear physicist cannot find a job commensurate with his training (or in a connected profession, to adequately put to use his knowledge and skills) in the destination country and becomes a taxi driver or a waiter. In this case, there is a mismatch between the skills provided by individuals and those required by the labour market, it is what the experts call a "brain loss". The literature on migration shows that such cases are not isolated.

The scarcity of literature on professional mobility served as a motivation to undertake such analyses for several decades (Shaw 1978; Harper 1995; Parrado et al. 2007), yet it remains largely reduced as compared to the literature on geographical mobility. One reason is that it is "it is very difficult to define quantitatively and measure an occupation" (Shaw 1978: 703). 
The standardization of occupational classification has been established in most developed countries, but the structure and relationships of a large number of occupational classifications are not yet identified or known.

The gravity model used in economics was developed by Tinbergen (1962) to explain trade flows, Lowry (1966) and then extended by various economic variables to represent the push and pull effects on people. Anderson (2010) and Head and Mayer (2013) provide large surveys of the literature in this domain, in order to identify many important determinants such as the network effect, the role of poverty constraints, the impact of cultural links between countries (Beine et al. 2014; Tubadji, Nijkamp 2015).

In the classical gravity model used to analyze migration, a flow from location $i$ to location $j$ is considered to be proportional to the population of the countries of origin and of destination ( $P i$ and $P j$ respectively) and inversely proportional to the distance between the two locations $f\left(d_{i j}\right)$, a being a constant related to mobility:

$$
M_{i j}=a \cdot P_{i} \cdot P_{j} \cdot f\left(d_{i j}\right) .
$$

The gravity model was extended by Molho (1986) to incorporate attraction factors, and therefore regional economic variables being considered as determinants of migration:

$$
M_{i j}=a \cdot P_{i} \cdot P_{j} \cdot f\left(d_{i j}\right) \times A_{i} B_{j},
$$

where: $A_{i}$ is the "pushing" factor in the country of origin and $B_{j}$ is the "pulling" factor of the host country.

Shuming Bao et al. (2008) developed specific versions of the model, which were used in the approach of inter-provincial migration. This model includes provincial investment and of the control of migrant networks, and of other various controls exerted on the characteristics of the province. The logarithm of the gross rate of inter-provincial emigration $\left(\log \left(M_{i j}\right)\right)$, calculated as the volume of emigration from province $i$ to province $j$ divided by the total inter-provincial migration in province $i$, is considered as the dependent variable:

$$
\begin{aligned}
\log M_{i j}= & \alpha_{0}+\alpha_{1} \log D_{i j}+\alpha_{2} \log N E T W O R K+\alpha_{3} \log F D I_{j i}+\alpha_{4} \log F A I_{j i}+ \\
& \alpha_{5}\left(\operatorname{og} F D I_{j i}\right)\left(\log F A I_{j i}\right)+\alpha_{6} \log Y_{j i}+\alpha_{7} \log E_{i}+\alpha_{8} \log E_{j}+\alpha_{9} \log U_{i}+ \\
& \alpha_{10} \log U_{j}+\alpha_{11} \log M A N E M P_{j i}+\alpha_{12} \log U R B A N_{j i}+ \\
& \alpha_{13} \log \text { MINORITY } Y_{j i}+\alpha_{14} \log W A R M_{j i}+\varepsilon_{i j} .
\end{aligned}
$$

In the model $D_{i j}$ denotes the distance by rail (in $\mathrm{km}$ ) between the capitals of provinces $i$ and $j$; NETWORK denotes the rate of past migration flows between the two provinces; $F D I_{j i}, F A I_{j i}$ and $Y_{j i}$ denote, respectively, the ratio between respectively the size of foreign direct investment per capita, the real domestic investment in fixed assets per capita, and real income per capita for the province $j$ and for the province $i$; $\mathrm{E}$ and $\mathrm{U}$ denotes the relative level of education respectively of unemployment rate in the two provinces $i$ and $j$; $M A N E M P_{j i}$ is the ratio between the share of employment in the manufacturing sector in province $j$ and the share of employment in the manufacturing sector in province $i$; URBAN $j i$ and MINORITY $Y_{j i}$ are the ratio between, respectively, the share of urban population respec- 
tively of minority population in the two provinces; $W A R M_{j i}$ is the ratio between the annual average temperature in the capital city of the two provinces; $\varepsilon_{i j}=$ the error term.

Cseres-Gergely (2004) proposes an analysis of internal migration in Hungary during the period 1994-2002. In his approach, the author starts from the basic gravity model:

$$
m_{i j}=g \frac{P_{i}^{\beta^{\prime}} \cdot P_{i}^{\beta^{\prime \prime}}}{d_{i j}^{\gamma}}
$$

where: $m_{i j}$ is the flow of migrants from region/country $i$ to region/country $j ; P_{i}$ and $P_{j}$ are "the size of the migration flows"; $d_{i j}$ the distance between region/country $i$ and region/ country $j$.

Although Newton's theory restricted the parameters $\beta^{\prime}=\beta^{\prime \prime}=1$, in terms of migration they can be assumed to be different from unity.

By logarithming this relation, we obtain the following linearized equation (Lowry extended it by adding economic variables as generalizations of $P_{i}$ and $P_{j}$ ):

$$
\ln m_{i j}=\alpha+\beta^{\prime} \ln P_{i}+\beta^{\prime \prime} \ln P_{j}-\gamma \ln d_{i j} .
$$

Although venerable, in the present juncture, when the data at micro-level are very detailed, this model is considered as outdated by many researchers. However, it is still used in cases where such data are not available. Because migration data are available at global scale, the gravity model seems to be a natural candidate.

Over time, different versions of the original gravity model were developed, in order to better describe the evolution of the economic phenomenon considered.

The introduction of the chain notion in the variant of the random utility model by McFadden (1973), where the decisive factor for those who live in location $i$ to choose a place to live in location $j$, with $j=\overline{1, J}$ possibilities, was based on the expected utility of living in a particular place over a period of time (see Schultz 1977). The utility deriving from such a movement can be written as $U_{i j}^{n}\left(Y_{j}, A_{j}, C_{i, j}, \mu_{j}^{n}\right)$, where $Y_{j}$ means income in location $j, A_{j}$ are amenities in $j, C_{j, i}$ are the costs of moving from location $i$ to and $\mu_{j}^{n}$ is the individual random earning. $P_{i j}$, the probability of moving from region $j$ to region $i$ is:

$$
P_{i j}=\operatorname{Pr}\left[U_{i j}=\max \left(U_{i 1}, U_{i 2}, \ldots, U_{i J}\right)\right] .
$$

McFadden's result shows that if $U_{i j}$ is linear in the logarithms of arguments and the logarithm of the original stochastic perturbation is independent and identical to the Weibull distribution, then the probability of moving from one place to another is given by the relation:

$$
P_{i j}==\frac{\exp \left(U_{i j}\right)}{\sum_{k=1}^{J} \exp \left(U_{i k}\right)}=\frac{\exp \left(\alpha_{1} \ln A_{j}+\alpha_{2} \ln Y_{j}+\alpha_{31} \ln C_{i j}\right)}{\sum_{k=1}^{J} \exp \left(\alpha_{1} \ln A_{k}+\alpha_{2} \ln Y_{k}+\alpha_{31} \ln C_{i k}\right)} .
$$

The probability of moving from $i$ to $j$, as compared to that of staying in $i$, a linear function depending on the differences between local characteristics:

$$
\ln \left(\frac{P_{i j}}{P_{i i}}\right)=\alpha_{1}\left(\ln A_{i}-\ln A_{j}\right)+\alpha_{2}\left(\ln Y_{i}-\ln Y_{j}\right)+\alpha_{3} C_{i j} \text {. }
$$


To estimate the proposed model, the author used data on inter-county migration because: i) there are no individual survey-level data that could be used to reliably estimate migration, ii) there are studies on wages and employment at the county level, therefore, the estimation of stimulation variables can be accurate in this case, iii) although the data on flows between NUTS 3 micro-regions are collected by the respective authority, such data are not disclosed to the public for confidentiality reasons.

In Hungary there are 20 counties (NUTS 2), with an average population of about 500,000 inhabitants (except Budapest, a city with a population of about 2 million people with atypical concentration and a high level of economic activity. The data analysed were national official statistical data and specific databases providing annual data for the period 1990-2002 regarding the settings, which can be aggregated at county level. Studies on wages carried out by the National Centre for Labour provided annual data on wages in firms with less than 11 employees since 1994, and quarterly data since 1993 for the employment of at least 80,000 people. Each variable was logarithmic, which excluded the possibility of zero migration from one region to another. To avoid this inconvenience, Poisson regressions were used to estimate the migration flows.

The explanatory variables are the following: gravitational variables (population and distance), variables related to the labour market, to the related housing market, as well as other indicators on the given county amenities.

On the basis of the evidence and methods presented in Köllo (2004) and Nagy (2004), the author calculated an additional set of variables related to conditions in the labour market, the level of education, potential experience (assumed from education), the local unemployment rate.

Also, a regional price index was introduced in the analysis of migration. Local amenities were represented by various factors, including the number of physicians per capita, of pediatricians, the number of tourists visiting the county (equivalent to a "commodity"), the number of criminal offences and suicides.

On basis of the available data, the author used in the study of inter-county migration in Hungary a regression in a rather general form:

$$
\ln M_{i j t}=\beta_{0} \ln M_{i j t}+\beta_{1} \ln A_{i t}+\gamma_{1} A_{j t}+\beta_{2} \ln Y_{i t}+\gamma_{2} Y_{j t}+\beta_{3} \ln C_{i j t}+g_{t}+f_{i j}+\varepsilon_{i j t},
$$

where, in addition to the variables already mentioned, $g_{t}$ ppears as a time effect variable, and $f_{i j}$ for specific effects.

\section{Study on Romanian emigration's evolution by using the gravity model}

For study the emigration in Romania an adaptable regression model based on the popular gravity model of migration was used, as available data provided by EUROSTAT (2016), TEMPO-Online (2016), World DataBank (2016), the Organisation for Economic Co-Operation and Development, the French Centre d'Etudes Prospectives et d'Informations Internationales (CEPII Research and Expertise on the World Economy 2011), are not comprehensive with regard to all exogenous variables in the gravity model. Therefore, we made an analysis of Romanian migration flows only to certain EU countries and at EU-27 level for the period 1995-2014. 
The exogenous variables considered are: the GDP of each country $i$ considered; the employment rate in industry for each country $i$; the unemployment rate for each country $i$; the volume of the Foreign direct investment (FDI) in each country $i$; the distance between Romania and the destinations of Romanian emigrants was calculated from the cities' longitude and latitude using the great circle formula (Mayer, Zignago 2011).

The model of the Romanian emigration to Spain is presented in Table 1.

The degree of dependence of the endogenous variable on all independent variables, which is of $86.19 \%$, indicates that the latter have a significant impact on the size of the Romanian migration to Spain. We used the variable Student $t_{v, \alpha}$, retrieved from the Student distribution table. For a significance level of $5 \%$, its value is 1.725 .

The analysis of the values calculated for each of the estimators determined indicates that for all, t-Statistic $>1.725$, so they are significantly different from zero. The probabilities of each estimator indicate that they are acceptable for the model considered.

The value of Durbin Watson statistic is 2.94 , which indicates that there is no autocorrelation of errors.

The $F$ test shows a value of 2.44, inferior to the $F$ distribution (Fisher-Snedecor) corresponding to the 8 degrees of freedom (10.70) and the significance threshold of 5\%. Therefore, the model is valid for use in the prognosis.

Table 1

\begin{tabular}{|c|c|c|c|c|}
\hline \multicolumn{5}{|c|}{$\begin{array}{l}\text { Dependent Variable: EMIGRSPAIN } \\
\text { Method: Least Squares } \\
\text { Sample: } 19952014 \\
\text { Included observations: } 20 \\
\text { EMIGRSPAIN }=\mathrm{C}(1)+\mathrm{C}(2)^{\star} \mathrm{GDPSP}+\mathrm{C}(3)^{\star} \mathrm{GDPRO}+\mathrm{C}(4)^{\star} \mathrm{RSSP}+\mathrm{C}(5)^{\star} \mathrm{RSRO}+\mathrm{C}(6)^{\star} \\
\text { EMPINDSP/EMPINDRO }+\mathrm{C}(7)^{\star}(\mathrm{FDIRO} / \mathrm{FDISP})+\mathrm{C}(8)^{\star} \mathrm{DISTANCE}\end{array}$} \\
\hline & Coefficient & Std. Error & $\mathrm{t}-$ Statistic & Prob. \\
\hline $\mathrm{C}(1)$ & 1787623. & 571124.4 & 3.130006 & 0.0087 \\
\hline $\mathrm{C}(2)$ & 2.972444 & 1.469810 & 2.022332 & 0.0660 \\
\hline $\mathrm{C}(3)$ & -0.388797 & 0.215702 & -1.802472 & 0.0966 \\
\hline $\mathrm{C}(4)$ & -8852.752 & 3183.593 & -2.780743 & 0.0166 \\
\hline $\mathrm{C}(5)$ & 54831.72 & 25617.79 & 2.140376 & 0.0536 \\
\hline$C(6)$ & 360349.6 & 180491.6 & 1.996489 & 0.0691 \\
\hline $\mathrm{C}(7)$ & -1691.968 & 837.2175 & -2.020942 & 0.0662 \\
\hline $\mathrm{C}(8)$ & -55953.32 & 24326.22 & -2.300124 & 0.0402 \\
\hline R-squared & 0.861960 & \multicolumn{2}{|c|}{ Mean dependent var } & 48799.85 \\
\hline Adjusted R-squared & 0.781437 & \multicolumn{2}{|c|}{ S.D. dependent var } & 51565.89 \\
\hline S.E. of regression & 24107.41 & \multicolumn{2}{|c|}{ Akaike info criterion } & 23.30760 \\
\hline Sum squared resid & $6.97 \mathrm{E}+09$ & \multicolumn{2}{|c|}{ Schwarz criterion } & 23.70589 \\
\hline Log likelihood & -225.0760 & \multicolumn{2}{|c|}{ Hannan-Quinn criter. } & 23.38535 \\
\hline F-statistic & 10.70451 & \multicolumn{2}{|c|}{ Durbin-Watson stat } & 2.940060 \\
\hline Prob(F-statistic) & 0.000252 & & & \\
\hline
\end{tabular}


For Italy, the actual data on the number of Romanian emigrants are available in several studies such as Alexandru (2011), or Mara (2012). In Table 2 there are presented the results of using the gravity model to study the Romanian migration.

The dependence of Romanian migration on all independent variables is of $76.05 \%$, which indicates that other exogenous variables are needed. This can be explained by the fact that the model should include other exogenous variables, possibly qualitative ones (e.g. family reunification, return to the place of origin, etc.), which are not available in the official statistics.

The calculated values indicates that only for some of the estimators $t_{\text {calc }}>1.725$, the others presenting values of less than 1.725 , but the vast majority of more than 1 . The DurbinWatson statistic shows the value 2.66, which indicates there is no autocorrelation of errors.

For Austria, it was possible to apply the gravity model in order to study Romanian emigration with a large number of exogenous variables. The analysis of the results presented in Table 3 shows that the explaining of Romanian emigration by means of the 7 exogenous variables is achieved in a proportion of $98 \%$ and the Durbin-Watson statistic (2.31) reveals that there is no autocorrelation of errors.

The $t$-Student statistic calculated for each estimator (except the seventh estimators) is much greater than the tabular value $t=1.725$, which indicates that they are significantly different from zero.

Table 2

\begin{tabular}{|c|c|c|c|c|}
\hline \multicolumn{5}{|c|}{$\begin{array}{l}\text { Dependent Variable: EMIGRITALY } \\
\text { Method: Least Squares } \\
\text { Sample: } 19952014 \\
\text { Included observations: } 19 \text { after adjustments } \\
\text { EMIGRITALY }=\mathrm{C}(1)+\mathrm{C}(2)^{\star} \mathrm{GDPRO}+\mathrm{C}(3)^{\star} \mathrm{GDPIT}+\mathrm{C}(4)^{\star} \mathrm{RSRO}(-1)+\mathrm{C}(5)^{\star} \mathrm{RSIT}(-1)+ \\
\mathrm{C}(6)^{\star}(\mathrm{INDIT} / \mathrm{INDRO}) \\
\mathrm{C}(7)^{\star}(\mathrm{FDIRO} / \mathrm{FDIIT})+\mathrm{C}(8)^{\star} \text { DISTINCE }\end{array}$} \\
\hline & Coefficient & Std. Error & $\mathrm{t}$-Statistic & Prob. \\
\hline $\mathrm{C}(1)$ & 1895044. & 955788.1 & 1.982703 & 0.0729 \\
\hline $\mathrm{C}(2)$ & -0.578814 & 0.284646 & -2.033453 & 0.0669 \\
\hline $\mathrm{C}(3)$ & 3.825179 & 1.441993 & 2.652703 & 0.0225 \\
\hline $\mathrm{C}(4)$ & 33127.73 & 25289.00 & 1.309966 & 0.2169 \\
\hline $\mathrm{C}(5)$ & -30221.82 & 9886.174 & -3.056978 & 0.0109 \\
\hline $\mathrm{C}(6)$ & 18565.00 & 310055.1 & 0.059876 & 0.9533 \\
\hline $\mathrm{C}(7)$ & -499.6557 & 1499.883 & -0.333130 & 0.7453 \\
\hline $\mathrm{C}(8)$ & -211076.7 & 153150.7 & -1.378229 & 0.1955 \\
\hline R-squared & 0.760521 & \multicolumn{2}{|c|}{ Mean dependent var } & 64994.47 \\
\hline Adjusted R-squared & 0.608125 & \multicolumn{2}{|c|}{ S.D. dependent var } & 66489.37 \\
\hline S.E. of regression & 41622.32 & \multicolumn{2}{|c|}{ Akaike info criterion } & 24.40622 \\
\hline Sum squared resid & $1.91 \mathrm{E}+10$ & \multicolumn{2}{|c|}{ Schwarz criterion } & 24.80388 \\
\hline Log likelihood & -223.8591 & \multicolumn{2}{|c|}{ Hannan-Quinn criter. } & 24.47352 \\
\hline F-statistic & 4.990423 & \multicolumn{2}{|c|}{ Durbin-Watson stat } & 2.666324 \\
\hline Prob(F-statistic) & 0.009250 & & & \\
\hline
\end{tabular}


Table 3

\begin{tabular}{|c|c|c|c|c|}
\hline $\begin{array}{l}\text { Dependent Variable: } \\
\text { Method: Least Squar } \\
\text { Sample: } 19952013 \\
\text { Included observation } \\
\text { EMIGRAUSTRIA = } \\
\mathrm{C}(6)^{*}(\text { INDAUT/IND }\end{array}$ & $\begin{array}{l}\text { GRAUSTRIA } \\
\text { after adjustn } \\
-\mathrm{C}(2)^{\star} \mathrm{GDPAL} \\
(-1)+\mathrm{C}(7)^{*}(\mathrm{FI}\end{array}$ & $\begin{array}{l}3)^{*} \mathrm{GDPRO}+ \\
\text { FDIAUT }(-1\end{array}$ & $\begin{array}{l}\text { SAUT }+C(5)^{\star} \\
\text { DISTANCE }\end{array}$ & $1)+$ \\
\hline & Coefficient & Std. Error & $\mathrm{t}-$ Statistic & Prob. \\
\hline $\mathrm{C}(1)$ & -131149.1 & 17220.54 & -7.615853 & 0.0000 \\
\hline $\mathrm{C}(2)$ & 0.042282 & 0.022177 & 1.906564 & 0.0857 \\
\hline $\mathrm{C}(3)$ & -0.049752 & 0.020171 & -2.466505 & 0.0333 \\
\hline $\mathrm{C}(4)$ & -1141.416 & 509.0095 & -2.242425 & 0.0488 \\
\hline $\mathrm{C}(5)$ & 940.7682 & 464.4897 & 2.025380 & 0.0703 \\
\hline $\mathrm{C}(6)$ & 12621.92 & 3985.705 & 3.166796 & 0.0100 \\
\hline $\mathrm{C}(7)$ & 162.5646 & 111.4776 & 1.458272 & 0.1754 \\
\hline $\mathrm{C}(8)$ & -7682.701 & 1252.710 & -6.132863 & 0.0001 \\
\hline R-squared & 0.986691 & \multicolumn{2}{|c|}{ Mean dependent var } & 6411.444 \\
\hline Adjusted R-squared & 0.977374 & \multicolumn{2}{|c|}{ S.D. dependent var } & 4378.068 \\
\hline S.E. of regression & 658.5413 & \multicolumn{2}{|c|}{ Akaike info criterion } & 16.11903 \\
\hline Sum squared resid & 4336767 & \multicolumn{2}{|c|}{ Schwarz criterion } & 16.51475 \\
\hline Log likelihood & -137.0713 & \multicolumn{2}{|c|}{ Hannan-Quinn criter. } & 16.17360 \\
\hline F-statistic & 105.9085 & \multicolumn{2}{|c|}{ Durbin-Watson stat } & 2.313933 \\
\hline Prob(F-statistic) & 0.000000 & & & \\
\hline
\end{tabular}

Romanian migration flows to Germany were more consistent in the early part of the last decade of the last century. The application of the gravity model for the proposed study, using the same variables as for the other countries, led to a high determination coefficient: $0.98, t$-Student statistic values greater than the table values (1.725) for most estimators (Table 4) and the Durbin-Watson statistic (2.36) reveals that there is no autocorrelation of errors.

If we consider the total number of Romanian emigrants to countries of the European Union, then the application of the model results in the following estimators (see Table 5).

The influence of the exogenous variables is in a proportion of $89.67 \%$, at a confidence level of $5 \%$ (Table 5 ).

The calculated values of the variable Student $t_{v, \alpha}$, for almost all estimators are higher than 1.725 , indicating that the model estimators are significantly different than zero.

The Durbin-Watson statistic shows a value of 2.84 , and therefore there is no autocorrelation of errors.

The $F$ test shows a value of 17.36, inferior to the $F$ distribution (Fisher-Snedecor) corresponding to the 7 degrees of freedom and the significance threshold of $5 \%\left(F_{t a b}=2.51\right)$. Therefore, the law of the evolution of migrants is stable over time, and the model, with all its drawbacks, can be used to achieve the forecast.

Panel data models consist in estimating regression equations that use series which are simultaneously time series and cross-sectional data. 
Table 4

\begin{tabular}{|c|c|c|c|c|}
\hline $\begin{array}{l}\text { Dependent Variable: } \\
\text { Method: Least Squar } \\
\text { Sample: } 19952014 \\
\text { Included observation } \\
\text { EMIGRGERMANY } \\
\text { RSGERM }(-2)+C(5)^{*}\end{array}$ & $\begin{array}{l}\text { IGRGERMA } \\
8 \text { after adjust } \\
1)+C(2)^{\star} \mathrm{GD} \\
\mathrm{O}+\mathrm{C}(6)^{\star}(\mathrm{IN}\end{array}$ & $\begin{array}{l}+\mathrm{C}(3)^{*} \mathrm{GDF} \\
\mathrm{R})+\mathrm{C}(7)^{\star}(\mathrm{I}\end{array}$ & $\begin{array}{l}4)^{\star} \\
\mathrm{DIG})+\mathrm{C}(8)^{\star} \mathrm{I}\end{array}$ & \\
\hline & Coefficient & Std. Error & t-Statistic & Prob. \\
\hline $\mathrm{C}(1)$ & -519772.2 & 269590.5 & -1.928006 & 0.0827 \\
\hline $\mathrm{C}(2)$ & 0.317185 & 0.055574 & 5.707416 & 0.0002 \\
\hline $\mathrm{C}(3)$ & -0.982996 & 0.435408 & -2.257645 & 0.0476 \\
\hline $\mathrm{C}(4)$ & -6408.598 & 3748.713 & -1.709546 & 0.1181 \\
\hline$C(5)$ & 16337.52 & 6851.697 & 2.384449 & 0.0383 \\
\hline $\mathrm{C}(6)$ & 132935.2 & 57645.46 & 2.306083 & 0.0438 \\
\hline $\mathrm{C}(7)$ & -168.7857 & 72.64995 & -2.323273 & 0.0425 \\
\hline $\mathrm{C}(8)$ & -11678.94 & 49648.32 & -0.235233 & 0.8188 \\
\hline R-squared & 0.983165 & Mean & ent var & 54699.00 \\
\hline Adjusted R-squared & 0.971381 & S.D. & nt var & 50792.06 \\
\hline S.E. of regression & 8592.575 & Akaik & riterion & 21.25629 \\
\hline Sum squared resid & $7.38 \mathrm{E}+08$ & Schn & erion & 21.65201 \\
\hline Log likelihood & -183.3066 & Hanna & n criter. & 21.31085 \\
\hline F-statistic & 83.43004 & Durbi & on stat & 2.364041 \\
\hline Prob(F-statistic) & 0.000000 & & & \\
\hline
\end{tabular}

Table 5

Dependent Variable: EMIGRUE

Method: Least Squares

Date: 11/03/16 Time: 21:17

Sample (adjusted): 19962014

Included observations: 19 after adjustments

EMIGRUE $=\mathrm{C}(1)+\mathrm{C}(2)^{*} \mathrm{GDPRO}(-1)+\mathrm{C}(3)^{*} \mathrm{GDPUE}+\mathrm{C}(4)^{*}(\mathrm{INDUE} / \mathrm{INDRO})+\mathrm{C}(5)^{*} \mathrm{RSRO}+$ $\mathrm{C}(6)^{\star} \mathrm{RSUE}+\mathrm{C}(7)^{\star} \mathrm{FDIRO}$

\begin{tabular}{ccccc}
\hline & Coefficient & Std. Error & t-Statistic & Prob. \\
\hline $\mathrm{C}(1)$ & -430222.3 & 338209.9 & -1.272057 & 0.2275 \\
\hline $\mathrm{C}(2)$ & -2.891119 & 1.415521 & -2.042442 & 0.0637 \\
\hline $\mathrm{C}(3)$ & 0.085065 & 0.030274 & 2.809853 & 0.0158 \\
\hline $\mathrm{C}(4)$ & 907825.7 & 402697.0 & 2.254364 & 0.0437 \\
\hline $\mathrm{C}(5)$ & 116733.3 & 42656.23 & 2.736605 & 0.0180 \\
\hline $\mathrm{C}(7)$ & -36173.73 & 19053.69 & -1.898515 & 0.0819 \\
\hline R-squared & -18.36486 & 9.817239 & -1.870674 & 0.0860 \\
\hline Adjusted R-squared & 0.896713 & Mean dependent var & 201074.8 \\
\hline S.E. of regression & 0.845070 & S.D. dependent var & 138193.0 \\
\hline Sum squared resid & 54394.41 & Akaike info criterion & 24.92322 \\
\hline Log likelihood & $3.55 \mathrm{E}+10$ & Schwarz criterion & 25.27117 \\
\hline F-statistic & -229.7706 & Hannan-Quinn criter. & 24.98211 \\
\hline Prob(F-statistic) & 17.36355 & Durbin-Watson stat & 2.846277 \\
\hline
\end{tabular}


With this type of model, we can determine the coefficient expressing the impact of a macroeconomic variable on the performance of a group of other indicators.

Panel data models allow:

- summarizing by a single coefficient the impact of a variable on a group of time-series dependent variables;

- estimating specific coefficients (constants or coefficients of independent variables) for each time-series considered as a dependent variable - fixed effects;

- grouping dependent variables in categories and estimating the impact of the category the dependent variable is part of on its evolution.

The impact of macroeconomic indicators on the evolution of the number of Romanian emigrants to the EU-27 was also estimated by means of the panel data methodology using the Eviews program, and resulted in a sample of 100 observations (Table 6).

Table 6

\begin{tabular}{|c|c|c|c|c|}
\hline \multicolumn{5}{|c|}{$\begin{array}{l}\text { Dependent Variable: LOG(EMIGRUE) } \\
\text { Method: Pooled Least Squares } \\
\text { Sample: } 19952014 \\
\text { Total panel observations: } 100\end{array}$} \\
\hline Variable & Coefficient & Std. Error & t-Statistic & Prob. \\
\hline LOG(GDPRO) & -1.327311 & 0.146855 & -9.038228 & 0.0000 \\
\hline LOG(INDRO) & -2.722180 & 1.371101 & -1.985396 & 0.0657 \\
\hline LOG(RSRO) & 2.575669 & 0.579232 & 4.446699 & 0.0005 \\
\hline LOG(FDIRO) & -0.129272 & 0.096142 & -1.344594 & 0.1987 \\
\hline $\mathrm{C}$ & -18.33028 & 5.189450 & -3.532220 & 0.0030 \\
\hline R-squared & 0.953992 & \multicolumn{2}{|c|}{ Mean dependent var } & 11.79941 \\
\hline Adjusted R-squared & 0.941723 & \multicolumn{2}{|c|}{ S.D. dependent var } & 1.000810 \\
\hline S.E. of regression & 0.241602 & \multicolumn{2}{|c|}{ Akaike info criterion } & 0.209264 \\
\hline Sum squared resid & 0.875569 & \multicolumn{2}{|c|}{ Schwarz criterion } & 0.458197 \\
\hline Log likelihood & 2.907361 & \multicolumn{2}{|c|}{ Hannan-Quinn criter. } & 0.257858 \\
\hline F-statistic & 77.75744 & \multicolumn{2}{|c|}{ Durbin-Watson stat } & 2.336419 \\
\hline
\end{tabular}

The analysis of the model estimators' values indicates that, with the growth of the Romanian GDP, the employment rate in industry, and of the foreign direct investment, the number of emigrants has declined. The rise of unemployment by 1 percent leads to an increase in the number of emigrants by 2.57 persons.

To conclude, the use of this model to estimate the number of Romanian emigrants is econometrically significant. These estimates, however, can be improved if longer and more detailed data series would be available.

Panel data models can be used to increase the number of observations for a global analysis of the studied phenomenon and to make a comparative analysis of the results obtained on the endogenous variable. 


\section{Conclusions}

For the study of migration, using the gravity model for estimating the number of (Romanian) emigrants can generate interesting results.

Some studies highlight the fact that individuals calculate the value of their human capital for each region or country and each individual assesses his/her return and costs in different manners, so that migration to a country may be useful to some people and not useful to others. Therefore, when analysing the migration flows, one should not only pay attention to the aggregate labour market variables (such as wages and the unemployment gap), but to individuals' heterogeneity as well.

Other empirical studies use aggregate databases in order to find a statistically significant positive effect of income in the host country, or the wage differences between the destination countries and origin countries, as well as a negative effect of the wages in the migrants' decision to return back home. Thus, it has been demonstrated that individuals are attracted to areas with jobs deficit, but also issues such as professional status and education are considered as major factors affecting the overall impact of migration.

For the study of emigration in Romania we used a simplified gravity model, due to the limited access or incomplete statistical data provided by the EUROSTAT (2016), TEMPOOnline (2016), World DataBank (2016), OECD.Stat (2016), the French Centre d'Etudes Prospectives et d'Informations Internationales (CEPII Research and Expertise on the World Economy 2011), which are not comprehensive with regard to all exogenous variables in the gravity model. Therefore, we made an analysis of Romanian migration flows only to certain EU countries and at EU-27 level for the period 1995-2014.

In the model, there were considered as exogenous variables the followings: the GDP of the destination country, the employment rate in industry and thethe unemployment rate also in the destination countries, the volume of the Foreign direct investment (FDI) in each destination country $i$, and the the distance between Romania and analysed destination countries for Romanian emigrants, which was calculated using the great circle formula (Mayer, Zignago 2011).

In the description of Romanian emigration to Spain, the degree of dependence of $86.19 \%$, indicates a significant impact on the size of the Romanian migration to Spain.

For Italy, the results indicate a dependence of Romanian migration of $76.05 \%$, which indicates the need for the use of other exogenous variables. This can be explained by the fact that the model should include other exogenous variables, possibly qualitative ones (e.g. family reunification, return to the place of origin, etc.), which are not available in the official statistics.

For Austria, it was possible to apply the gravity model in order to study Romanian emigration with a large number of exogenous variables. The analysis of the results shows that the explaining of Romanian emigration by means of the 7 exogenous variables is achieved in a proportion of $98.66 \%$ and the Durbin-Watson statistic reveals that there is no autocorrelation of errors. 
Romanian migration flows to Germany were more consistent in the early part of the last decade of the last century. The application of the gravity model for the proposed study, using the same variables as for the other countries, led to a high determination coefficient: $0.98, t$-Student statistic values greater than the table values for most estimators (Table 4) and the Durbin-Watson statistic (2.36) reveals that there is no autocorrelation of errors

Panel data models consist in estimating regression equations using series which are simultaneously time series and cross-sectional data.

With this type of model, we can determine the coefficient expressing the impact of a macroeconomic variable on the performance of a group of other indicators.

The impact of macroeconomic indicators on the evolution of the number of Romanian emigrants to European Union was also estimated by means of the panel data methodology using the Eviews program.

The analysis indicates that, with the growth of the Romanian GDP, the employment rate in industry, and of the foreign direct investment, the number of emigrants has declined. The rise of unemployment by 1 percent generate a growth of 2.57 emigrants.

Several ways to improve the estimation would include further analysis, using more data, especially longer data series, more detailed information on the number of Romanian emigrants, introducing other exogenous variables, introducing more qualitative variables and reconsidering some of them etc.

\section{References}

Alexandru, M. 2011. Occupational mobility in the context of international migration. The case of Romanian migrants in Italy, The Romanian Journal of Society and Politics 6(2).

Anderson, J. E. 2010. The gravity model. NBER Working Paper 16576.

Andrén, D.; Roman, M. 2014. Should I stay or should I go? Romanian migrants during transition and enlargements. IZA and CELSI. Discussion Paper No. 8690.

Arpaia, A.; Kiss, A.; Palvolgyi, B.; Turrini, A. 2014. Labour mobility and labour market adjustment in the EU. European Commission, Directorate-General for Economic and Financial Affairs, Brussels.

Badulescu, D.; Badulescu, A.; Bucur, C.-A. 2015. Considerations on the effectiveness of cross-border cooperation in public order and civil protection services. The case of the Romanian - Hungarian border area, Lex Localis-Journal of Local Self-Government 13(3): 559-578.

https://doi.org/10.4335/13.3.559-578(2015)

Badulescu, D. 2007a. Foreign direct investment in the World - trends and structural issues (II- Towards FDI in New Sectors and New Emerging Economies), The Annals of the University of Oradea. Economic Sciences 16(1): 51-54.

Badulescu, D. 2007b. Globalizarea şi băncile. Cu o privire specială asupra Europei Centrale şi de Est şi asupra României. Economica Publishing House, Bucharest.

Beine, M.; Bertoli, S.; Fernandez-Huertas Moraga, J. 2014. A practitioners' guide to gravity models of international migration. Fedea Working Paper 03.

Center for Urban and Regional Sociology (CURS) 2005. Survey conducted for the Anti-Discrimination National Council [online], [cited 9 October 2013]. Available from Internet: http://www.curs.ro/ uploads/raport\%20sondaj\%20discriminare.pdf. 
CEPII Research and Expertise on the World Economy. 2011. GeoDist [online], [cited 10 November 2013]. Available from Internet: http://www.cepii.fr/CEPII/en/bdd_modele/presentation.asp?id=6

Cseres-Gergely, Z. 2004. County to county migration and labour market conditions in Hungary between 1994 and 2002, Zeitschrift für ArbeitsmarktForschung-Journal for Labour Market Research 37(4): 425-436.

Diminescu, D. 2009. The difficult exercise of free movement: an introduction to the recent migration history of the Romanians, in R. G. Anghel, I. Horvath (Eds.). Migration sociology. Romanian theories and case studies. Polirom Publishing House, Iasi.

Harper, B. 1995. Male occupational mobility in Britain, Oxford Bulletin of Economics and Statistics 57: 349-369.

Head, K.; Mayer, T. 2013. Gravity equations: workhorse, toolkit and cookbook. CEPII Working Paper No. 27.

IOM. 2008. Migration in Romania: a country profile. International Organization for Migration [online], [cited 15 May 2011]. Available from Internet: http://www.iom.hu/PDF/migration_profiles2008/Romania_Profile2008.pdf.

IOM. 2005. Risks of irregular migration to EU countries 2003-2005: what has changed?. IOM Mission in Romania, 2005. Bucharest.

Köllo, J. 2004. Regional differentials in earnings and labour costs, in Zs. Cseres-Gergely, K. Fazekas, J. Koltay (Eds.). The Hungarian labour market in focus. IEHAS, Budapest.

Lang, T.; Hämmerling, A.; Keil, J.; Nadler, R.; Schmidt, A.; Haunstein, S.; Smoliner, S. 2012. Re-Turn Migrant Survey Report: The Migrants' Potential and Expectations [online], [cited 15 June 2014]. Available from Internet: http://www.re-migrants.eu/download/323_Migrant-Survey-Report.PDF.

Lowry, I. 1966. Migration and metropolitan growth: two analytical models. San Francisco: Chandler.

Mara, I. 2012. Surveying Romanian migrants in Italy before and after the EU accession: migration plans, labour market features and social inclusion. The Vienna Institute for International Economic Studies

Martin, R.; Radu, D. 2012. Return migration: the experience of Eastern Europe, International Migration 50(6): 109-112.

Mayer, T.; Zignago, S. 2011. Notes on CEPII's distances measures: the GeoDist database. CEPII, WP No 2011-25: 7-12.

McFadden, D. 1973. Conditionial logit analvsis of qualitative choice behavior, in P. Zaremiibka (Ed.). Frontiers in Econometrics. New York: Wiley, 105-135

Molho, I. 1986. Theories of migration: a review, Scottish Journal of Political Economy 33(4): 396-419.

Nagy, Gy. 2004. Regional differences in employment probability, in Zs. Cseres-Gergely, K. Fazekas, J. Koltay (Eds.). The Hungarian labour market in focus. IEHAS, Budapest.

OECD.Stat. 2016. International Migration Database [online], [cited 14 June 2016]. Available from Internet: https://stats.oecd.org/Index.aspx?DataSetCode=MIG

Parrado, E. A.; Flippen, C. A.; McQuiston, C. 2007. Use of commercial sex workers among Hispanic migrants in North Carolina: implications for the spread of HIV, Perspectives on Sexual and Reproductive Health 36(4): 150-156. https://doi.org/10.1363/3615004

Ravenstein, E. G. 1885. The laws of migration, Journal of the Statistical Society of London 48(2): 167235. https://doi.org/10.2307/2979181

Sandu, D. 2006. Living abroad on a temporary basis. The economic migration of Romanians: 1990-2006 [online], [cited 7 June 2011]. Open Society Foundation, Bucharest. Available from Internet: http:// www.fundatia.ro/sites/default/files/en_52_Living\%20abroad\%20on\%20a\%20temporary\%20basis. pdf. 
Schultz, T. P. 1977. A conditional logit model of internal migration: Venezuelan lifetime migration within educational strata. Discussion Paper No. 226. Economic Growth Center, Yale University.

Sjaastad, L. A. 1962. The costs and returns of human migration, The Journal of Political Economy: 80-93. https://doi.org/10.1086/258726

Shaw, R. P. 1978. Migration theory and fact: a review and bibliography of current literature. Bibliography Series No. 5. Regional Science Research Institute: Philadelphia, Pennsylvania.

Shuming Bao; Bodvarsson, O. B.; Hou, J. W.; Yaohua, Zhao, 2008. The deregulation of people flows in China: did the structure of migration change, The Indian Journal of Labour Economics 51(4): 533-548.

Tinbergen, J. 1962. Shaping the world economy: suggestions for an international economic policy. New York: The Twentieth Century Fund.

Tubadji, A.; Nijkamp, P. 2015. Cultural gravity effects among migrants: a comparative analysis of the EU15, Economic Geography 91(3): 343-380. https://doi.org/10.1111/ecge.12088

UNDP. 2007. Making EU Accession Work for All. Fostering Human Development by Strengthening the Inclusiveness of the Labour Market in Romania. National Human Development Report - Romania, 2007. Bucharest.

EUROSTAT. 2016. [online], [cited 26 September 2016]. Available from Internet: http://ec.europa.eu/ eurostat/web/population-demography-migration-projections/migration-and-citizenship-data/database.

TEMPO-Online. 2016. [online], [cited 20 September 2016]. Available from Internet: http://statistici. insse.ro/shop/index.jsp?page=tempo2\&lang=ro\&context $=12$.

World DataBank. 2016. [online], [cited 24 September 2016]. Available from Internet: http://databank. worldbank.org/data/home.aspx.

Nicolaie IANCU. PhD in Economics, associate teaching staff at Agora University of Oradea, Chief Police Commissioner of the Territorial Border Police Inspectorate of Oradea, Founder of the Euro Regional Centre for the Prevention and Fight Against Cross-Border Criminality, Oradea, Romania; Trainer. The main directions of interest and advanced research are Economics and International Migration. Author/coauthor of 6 specialized books, author/coauthor of 26 articles, director or member of 3 grants/international or national.

Alina BADULESCU is Professor of Economics and PhD. coordinator at the Faculty of Economic Sciences and Doctoral School in Economics within the University of Oradea, Romania. Graduated Bucharest University of Economics (1992) and earned her doctor degree in Economics at Babes-Bolyai University (1997). Currently, she holds the position of dean of the Faculty of Economic Sciences, University of Oradea. Her research interests include economic development, entrepreneurship and sustainable development, having authored 16 ISI-indexed articles, and numerous journal articles, chapters and books.

Ramona-Mihaela URZICEANU. PhD Associate Professor of Department of Social Sciences, Faculty of Law and Economic Sciences-Agora University of Oradea, Romania. Head of HR Department, Agora University of Oradea, Romania. 
Elena-Ana IANCU. PhD in Law with a CUM LAUDE distinction, Professor at Agora University of Oradea municipality, with 19-year seniority in higher education, head of the Social Sciences Department, Faculty of Law and Economics; Jean Monnet Professor, holder of the module entitled "The Free Movement of Persons within the European Union"; Founder and Director of the Euroregional Centre for the Prevention and Fight against Cross-Border Criminality, Oradea, Romania; Trainer; Expert evaluator for The Romanian Agency for Quality Assurance in Higher Education (ARACIS) in the Law field. The main directions of interest and advanced research are Forensic Science and Criminal Law. The Special Part, and the directions of interdisciplinary study are Forensic Science - International Migration, Forensic Science - Legal Sociology. Author/coauthor of 7 specialized books, author/coauthor of 82 articles, author of 1 research within the fundamental program of the Romanian Academy, author of 1 book of poetry. Director or member of 17 grants/international or national projects and coordinator of 1 international research team and member of 2 international research teams. Founder and Conference Chair of numerous international conferences, debates and international summer schools; founder and editor-in-chief of an internationally-circulated journal in Law field and founder of journal in Administratives Scientifices field.

Ramona SIMUT is Doctor in Economics, Assistant Professor at the Department of Economics, Faculty of Economic Sciences, University of Oradea. She has a master degree in Business Administration (2010), PhD in Economics (2014) and post-doctoral studies in Economics (2015). Her research interests include economic convergence, sustainable development and applied statistical and econometrical methods. 